\title{
Impact of Foreign Direct Investment on Economic Growth in Central and Eastern European Countries
}

\author{
Petr Hlavacek ${ }^{1}$, Beata Bal-Domanska ${ }^{2}$ \\ ${ }^{1}$ University of Jan Evangelista Purkyne \\ 40096 Usti nad Labem, Czech Republic \\ E-mail.petr.hlavacek@ujep.cz. \\ ${ }^{2}$ Wroclaw University of Economics \\ 58-500 Jelenia Gora, Poland \\ E-mail.beata.bal-domanska@ue.wroc.pl
}

cross $^{\text {ref }}$ http://dx.doi.org/10.5755/j01.ee.27.3.3914

\begin{abstract}
The paper seeks to analyse foreign direct investment and its impact on economic growth in the Central and Eastern European countries between 2000 and 2012, with an emphasis on the Czech Republic, Estonia, Hungary, Latvia, Lithuania, Poland, Slovakia and Slovenia. The methodology applied in the first part involved comparative analysis of the trends in foreign investment and gross domestic product, and in the other, a growth model based on the Endogenous Growth Model.

The analysis implied a great deal of spatial differentiation in the inflow of foreign investment and in economic growth. Estonia, followed by Hungary, the Czech Republic, and Slovakia by margin reports the highest volume of foreign direct investments for production of the gross domestic product and when recalculated to the manpower. Lower influence of the foreign direct investments on the economy was reported for Lithuania, Poland, Latvia, and Slovenia.

In the second part, a growth model is compiled, which revealed that statistically significant relations exist between economic growth, FDI and investment growth. Growth of foreign direct investment positively demonstrates itself in increasing the level of the gross domestic product. The influence of foreign direct investment on economic growth of the Central and Eastern European countries was more visible in the period of 2009-2012.
\end{abstract}

Keywords: Foreign Direct Investment, Gross Domestic Product, Central and Eastern Europe, Growth Model.

\section{Introduction}

Central and Eastern European countries (CEEC) were markedly economically underdeveloped in comparison to Western European countries, they did not have adequate resources and technological levels, and their growth was therefore conditioned by major foreign investment. As a result of political changes, the transformation of the centrally controlled economy to the capitalist market economy changed the development processes of these countries. Rapacki \& Prochniak (2009), Estrin, Hanousek, Kocenda \& Svejnar (2009) analyze the transformation processes and changes the transition CEEC economies. It was expected that the foreign investors would bring investments, know-how, new management methods, and new export potential. According to Bandelj (2010), the striving of the countries for the inflow of the foreign direct investments at the time of accession to the EU should point out to their attractiveness and successful integration in the global economy. The foreign direct investments in the transition economies in the CEE countries become one of the basic criteria of successful economic transformation.

The paper focuses on selected Central and Eastern European countries (Czech Republic, Estonia, Hungary, Lithuania, Latvia, Poland, Slovakia, Slovenia), who, owing to their geographical location, political-economic development, are forming open economies, in which foreign investment has an important role to play. The views on the geo-political definition of the area of the transitive economies, and particularly geographic inclusion of the Baltic countries, differ. This group of countries was included in Central Europe for analysis of the transformation processes (Kornai, 2006). The countries, on which the research focuses, are more often classified as the countries of Central and Eastern Europe in the bibliography. Yet another reason for the selection of these countries is the political factor, as it is the first group of postsocialist states that acceded to the European Union in 2004.

The paper draws on studies (Curwin \& Mahutga, 2014; Kornecki \& Raghavan, 2011; Leibrecht \& Riedl, 2014) that addressed the development of transitional or development economies with an emphasis on the role of foreign direct investment. The investigation into transformation processes in the CEE countries approaches foreign investment from various points of view, ranging from their share in the economy or in selected sectors (Pavlinek, 2012; Popescu, 2007) up to the impact on technological advancement (Bucar, Rojec \& Stare, 2009), or institutional quality (Tun, Azman-Saini \& Law, 2012).

The study of foreign direct investment is also coupled with analyses of global production chains and geographical distribution of production (Blažek, 2012). An independent approach consists in evaluating direct investment from the geographical point of view where its concentration is followed from the macro-regional to interregional level (Hardy, Micek \& Capik, 2012), often through comparing the differences or similarities in selected territorial phenomena 
and characteristics. For the CEE countries, the macroregional level is related, as an example, to the analyses completed by Carstensen \& Troubal (2004), Turnock (2005), Ginevicius \& Simelyte (2011) which addressed the impact of foreign direct investment on the transformation of national economies or selected sectors in selected countries. With regards to foreign direct investment on lower territorial levels, studies prevail, which deal with the penetration of foreign direct investment in the individual CEE countries. For the Baltic countries (Yucel, 2014), analyses of the impact of DFI on the economies of Lithuania or Estonia (Tvaronaviciene \& Grybaite, 2007; Ginevicius \& Tvaronaviciene, 2005) or Latvia (Revina \& Brekis, 2009), and of the impact of globalisation processes on Lithuania, Latvia and Estonia contained in the paper by Ginevicius \& Tvaronaviciene (2003) deserve to be mentioned here. Further studies which dealt with the inflow of foreign investment to other Central and Eastern European countries, namely Hungary (Boudier-Bensebaa, 2005), Poland (Gorynia, Nowak \& Wolniak, 2007), the Czech Republic (Tousek \& Tonev, 2003; Hlavacek \& Koutsky, 2013; Hlavacek, 2009), Slovakia (Wokoun, Tvrdon \& Damborsky, 2010) and Slovenia (Bucar, Rojec \& Stare, 2009) were also published.

The purpose of the article is to identify the impact of foreign direct investment on economic growth in selected Central and Eastern European countries, with an emphasis on post-2000 development. This is followed by compiling a model based on the Endogenous Growth Model (Mankiw, Romer \& Weil, 1992) processed according to Solow's neoclassical growth model. The model employs such indicators as gross domestic product per capita, inward foreign direct investment stock per capita, gross fixed capital formation per capita, increase in labour force, human resources in science and technology as the percentage of active population, which are followed for each country between 2000 and 2012. The construction of the model seeks to assess the impact and relevance of selected economic factors, including foreign direct investment, with regard to the economic growth of transitional economies in Central and Eastern European countries. Intensively, how foreign direct investment in transitional economies contributes to the development process in the individual countries.

\section{Development of the Economy and Inflow of Foreign Direct Investment}

What rendered these countries attractive for foreign direct investments was the privatisation process, where the countries privatised a sizable amount of major enterprises of pivotal significance to their national economies. The rate of these privatisation processes, the transformation of the economies as well as the establishment of functional security markets, which allowed portfolio investments, all had a significant role to play in the territorial differentiation of foreign direct investment.

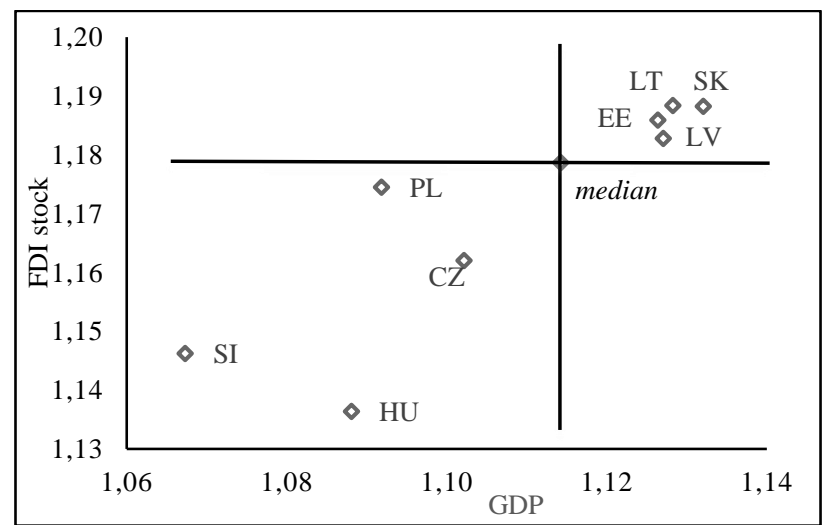

Figure 1. Average growth rate of gross domestic product and the stock of the foreign direct investments (FDI) per capita (USD) in Central and Eastern European countries in the period of 20002012 (USD)

Source: Author's compilation based on UNCTAD data

After 2000, the rate of economic growth increases and the economies enter a conjunctural stage of the economic cycle (Figure 1). This period was also coupled with growth in foreign direct investment, while the accession of the Central and Eastern European countries to the European Union in 2004 also had a positive role to play by strengthening the process of political and, first and foremost, economic integration in the European Economic Area.

The Gross Domestic Product growth remained above the EU level in all the countries during the period following the EU accession until 2008, when the macro-region also came down with the effects of the global economic crisis. In 2009 GDP growth slumped abruptly with only Poland managing to sustain its long-term growth owing to its economy being more closed in nature. The effects of the economic crisis were most profound in Lithuania, Latvia and Estonia, where the GDP slump approached the limit of $15 \%$. On the contrary, the Baltic countries' economies shook off the crisis effects rather quickly, registering aboveaverage rates of growth. Slovakia and Poland did not level the growth of the Baltic economies, yet their own economic growth was markedly higher than that of the European Union. The last group comprises of the Czech Republic, Hungary and Slovenia, where the rate of growth in the crisis period starting in 2008 was the lowest and often under the EU level. According to Prochniak (2011), this is due to the fact that less developed countries tend to grow faster, on average, compared to more developed countries. The hypothesis stands for Slovenia and the Czech Republic, which have two of the highest GDP per capita levels of all the Central and Eastern European countries. 

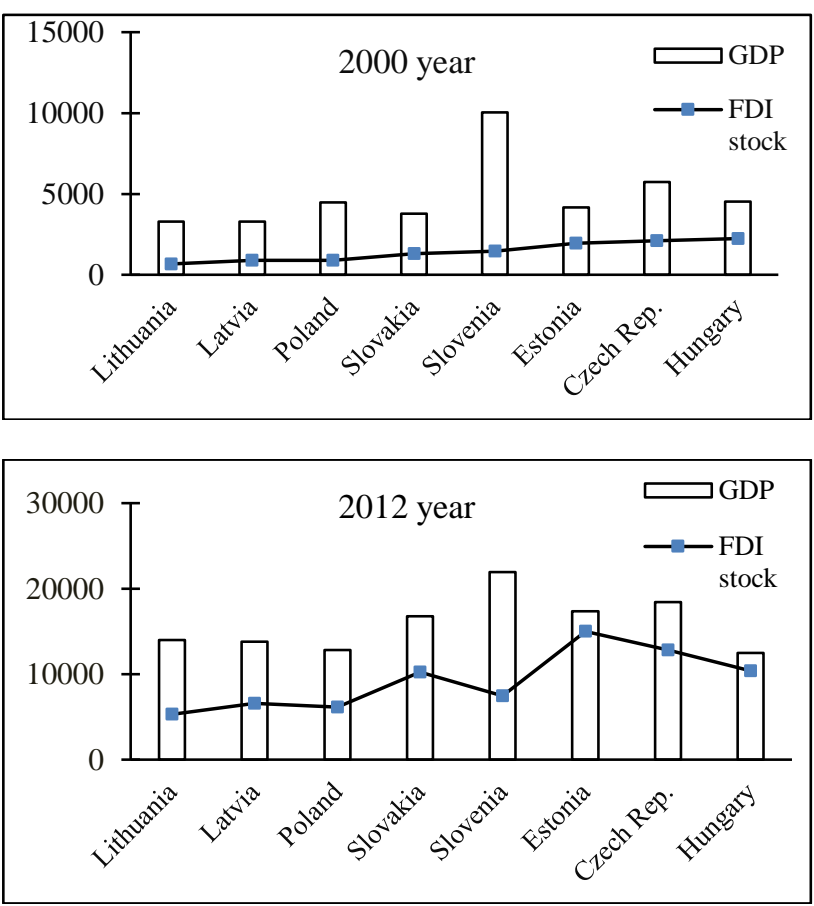

Figure 2. Gross domestic product (GDP) per capita (USD) and the stock of the foreign direct investments (FDI) per capita (USD) in Central and Eastern European countries 2000 and 2012

Source: Author's compilation based on UNCTAD data

In the countries under consideration, the volume of foreign direct investment and the gross domestic product grew from 2000 to 2012. The final number is shown in Figure 2 showing the overall foreign direct investment volume and gross domestic product per capita. Figure 2 shows the position of the individual countries based on the average rate of GDP growth and the volume of foreign direct investment between 2000 and 2012. The highest growth in foreign direct investment is reported by Slovakia, Lithuania and Estonia, where the average value of invested foreign capital grew by $20 \%$. In the Czech Republic, Latvia and Poland, the stock of FDI grew roughly by $17-18 \%$ per annum. On the contrary, a sloppier growth was observed in Slovenia $(15 \%)$ and the lowest number was reported in Hungary (14\% per annum). The varying rates of growth are also down to the overall investment volume during the years preceding 2000, when the countries in which the privatisation process had been completed, and which had already been open to foreign investment, had already achieved a higher volume of foreign investment per capita.

The comparison of the gross domestic product per capita and volume of FDI per capita shows the important differences between individual countries. Figure 2 illustrates total volume of the foreign direct investments and gross domestic product per capita in 2000 and 2012. High share of the foreign direct investments was seen in Estonia, in which a total share of foreign direct investments per capita amounted to almost $87 \%$ of the GDP per capita, and in Hungary $(83 \%)$. The Czech Republic and Slovakia follows with a margin where the share did not exceed $70 \%$. The lower share of the foreign direct investments was reported in Latvia and Poland (48\%), and lowest figures were reported from Lithuania (38\%) and Slovenia (34\%). In parallel with ending the privatization process, the greenfield investments started in the said countries and they aimed at making a share in the internal markets (market-seeking investments) or at using lower production costs (factor seeking investments) and to export the production of the new branches to markets in Western Europe.

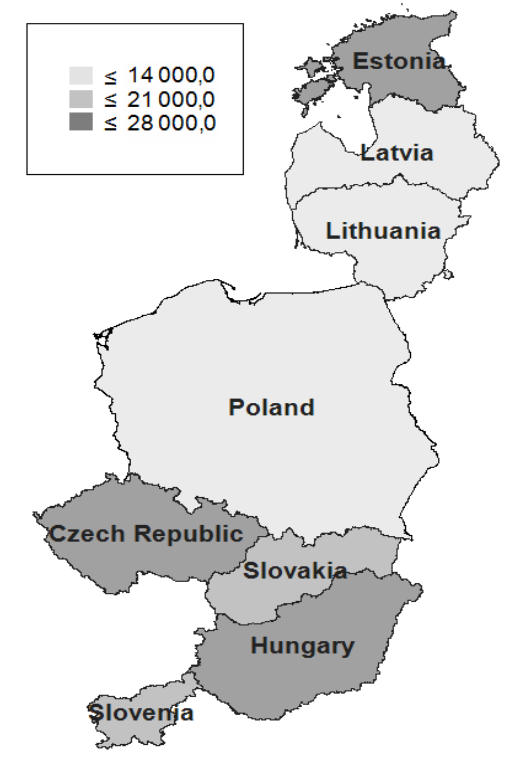

Figure 3. FDI stock per labour force in 2012 (USD) Source: Author's compilation based on UNCTAD data

The developments in spatial distribution of foreign direct investment per labour force until 2012 are markedly uneven among the countries. The spatial differences between the countries in the volume of foreign direct investment per labour force achieved until 2012 are shown in Figure 3. The countries may be divided into three categories by the quantity of investment. The highest volume of foreign direct investment per labour force was reported in Estonia, Hungary and the Czech Republic. These countries received the highest investments thanks to developed economic links to neighbouring countries, Scandinavia in the case of the Baltic countries and Germany in the case of the Czech Republic. Slovakia and Slovenia are included in the second group. Slovenia rather stagnates but in the case of Slovakia, in recent years and particularly before the economic crisis, above-than-average economic growth has been seen including stronger export focus of the economy contributed by the growth of the direct foreign investments. For example, Slovak automotive industry belongs among the biggest producers of passenger cars in Europe when recalculated per capita where the production is intended particularly for export.

The third group includes Lithuania, Latvia, and Poland, which despite the fact it has the strongest economy of all monitored countries but relatively less open for foreign investments.

The accession to the European Union in 2004 positively influenced the inflow of direct foreign investment because it brought free movement of goods and services to EU Single Market, political stability, and improved the economic environment for foreign investors. According to UNCTAD data for pre and post-2004, the development in of foreign direct investment demonstrates that the inflow of 
foreign direct investment was higher following the accession than before 2004 in all analyzed countries. As far as differences among the countries are concerned, a higher inflow of direct foreign investment was observed in Lithuania, Latvia, Poland, and Slovakia; the lowest inflows were observed in Hungary and Slovenia although still higher than before accession to the EU. The higher inflow of direct foreign investment also helped to economic growth and production capacity, especially in the export area. Foreign investors also began to re-invest their profits in the domestic economies, which can be interpreted as an expression of increased confidence in the economic environment of the new member countries. CEE countries offer a number of comparative advantages compared to Western European countries, including lower wage costs (Gauselmann, Knell \& Stephan, 2011). However, in recent years, we have seen the interest of foreign investors drop as a result of the economic crisis and growth of competition in the Balkan countries and Turkey.

\section{The Specification of Models and Statistical Data}

Solow neoclassical growth model constitutes the starting point in the discussion referring to the significance of foreign direct investments targeted at the Central and Eastern European countries development. Aggregate production function for the unique final good, in its version related to the concept of endogenous growth, augmented by human capital (Mankiw, Romer \& Weil, 1992 - hereinafter referred to as MRW) can be, in its general form, described as:

$$
Y(t)=K(t)^{\alpha} H(t)^{\beta}(A(t) L(t))^{l-\alpha-\beta}
$$

which means that at any $(t)$ time moment economy has a certain capital $(K)$, human capital $(\mathrm{H})$, labour $(L)$ and knowledge $(\mathrm{A})^{1}$ at its disposition, which are joined together in order to produce a product/income $(Y)$. In the above equation $\alpha, \beta$ parameters represent elasticity regarding the selected production factor. It can be assumed that $\alpha+\beta<1$ implies that there are decreasing returns to scale to all capital. It is also possible to assume that $\alpha+\beta=1$, which implies that there are constant returns to scale in the productivity factors.

The theory of endogenous growth ruled out the neoclassical assumption inherent in growth models regarding the exogenous nature of the technological level and human capital, regarding these indicators as endogenous factors of economic growth.

Knowledge and human capital constitute important factors of endogenous economic growth. The reason is the opinion that the rate of technological and human capital growth results out of individual decision-making and priorities of entities acting reasonably. The initial level of human capital is one of the basic factors influencing development. Countries featuring a higher initial level of human capital resources absorb knowledge and innovation at a faster pace, which manifests itself in higher growth rate. Knowledge influences income in a different way than human capital. As (Romer, 1986; Romer, 1990) indicates knowledge, regardless of its type, does not result in competition. Its implementation by one enterprise does not reduce opportunities for its application by another entity. Knowledge can be preserved; it does not disappear together with its creator's disappearance. It is, however, often protected by ownership rights, since it is created as the result of investing private outlays in research and development processes. Spillovers created by knowledge represent its crucial characteristics, which mean that investments carried out by some enterprises are also associated with advantages for others; however, no simultaneous remuneration occurs in the form of market price. As the result joint benefits resulting from knowledge are larger than just the sum of benefits experienced by individual entities (Tokarski, 2005).

The implementation of knowledge as an element of development requires certain resources' presence in a given country (human capital, infrastructure), which altogether allow for the full implementation of overall advantages resulting from knowledge and its effects in the form of e.g. advanced technologies. It raises the idea of the existence of a certain critical volume of economy saturation with its basic production factors, which facilitates full implementation of knowledge and its effects. One can refer to the absorption capacity of countries, allowing for new solutions (innovation) assimilation and implementation. Such capacity is very limited in the case of an extensive developmental gap occurrence. On the other hand, if this gap is small the capacity is big, but there are few solutions possible to be acquired by a transfer. One may expect that countries presenting an intermediate stage, i.e. in between of these very poorly and very well developed ones, will experience the fastest development rate (Gomulka, 2008).

The above mentioned Solow neoclassical growth model through Cobb-Douglas production function is frequently used to describe processes related to selected factors' impact on regional development. The production function illustrates the relation between production (economy) volume and the level of production factors outlays. The source of production growth (income, economy), in the model, takes the form of either increasing outlays or their implementation efficiency.

In the accepted study model construction, the factors influencing economic growth level were the ones in line with MRW model structure (capital, human resources and human capital). The distinctive component in the model, as compared to a standard MRW model structure, is represented by an inward foreign direct investment stock. This parameter illustrates the size of foreign capital captured by a given country, which results not only in infrastructure development and opening more jobs, but also enhances innovation and human capital quality increase. The model can be presented in the following way:

$$
\begin{aligned}
& \ln G D P_{i t}=\beta_{1} \ln F D I_{i t}+\beta_{2} \ln G F C F_{i t}+\beta_{3} \ln \left(n_{i t}+g+\delta\right) \\
& +\beta_{4} \ln H R S T_{i t}+\beta_{5} C R_{t}+\alpha_{i}+\alpha_{t}+\varepsilon_{i t} \\
& \varepsilon_{i t} \sim \operatorname{IID}\left(0, \sigma_{\varepsilon}^{2}\right)
\end{aligned}
$$

where:

\footnotetext{
${ }^{1} A(t) L(t)$ is reffered to as Harrod-neutral technological progress, which can be define as improvements in technology that increase the efficiency of
} 
$\beta$ - coefficients illustrate the impact of particular factors (explanatory variables) on the level of economic development.

$\varepsilon_{\text {it }}$ - error represents unobserved shocks in each time period and country.

$G D P_{i t}$ - gross domestic product per capita (US Dollars), refers to the size and level of economic growth in $i$-th country and $t$-th year.

$F D I_{i t}$ - inward foreign direct investment stock (annual) per capita (US Dollars), indicates the size of capital invested in the form of foreign direct capital investments in $i$-th country and $t$-th year.

$G F C F_{i t}$ - gross fixed capital formation less direct foreign investment flow per capita (US Dollars), illustrates investment less the means flowing in as direct foreign investments presented by $F D I_{i t}$ variable in $i$-th country and $t$-th year.

$\left(n_{i t}+g+\delta\right)$ - labour force growth rate augmented by the depreciation rate and technical advancement rate. It is assumed that the depreciation rate and technical advancement rate $(g+\delta)$ are constant across countries and time. $g+\delta$ were set at the standard level of 0,05 accepted in most research (Mankiw, Romer \& Weil, 1992).

$H R S T_{i t}$ - human resources in science and technology as the percentage of active population (\%) - refers to persons fulfilling one of the following conditions: either having successfully completed tertiary education level in S\&T field of study, although not formally qualified as above, or employed in S\&T occupation where the above qualifications are normally required. Human resources in science and technology represent the most creative part of human resources, which may have the highest impact on innovation in particular countries.

Two important events were recorded in the studied period. In 2004 these countries jointed the EU structures and in 2008 the economic crisis took place. Based on the observation of the GDP values in the analysed period it is noticeable that the accession to EU structures did not change the earlier trends for GDP per capita and thus it is not covered in the model. However, a well noticeable change in GDP trends, as a result of the 2008 crisis, is observed. GDP value per capita, in all studied countries, was growing till 2008, whereas after 2009 these tendencies stopped and in the period 2009-2010 a drop in GDP level per capita was recorded. In order to reflect it in the model, a binary variable was introduced $C R_{1}$ - additional binary variable for time after the 2008 crisis $\left(C R_{l}=1\right.$ if $\left.t=2009,2010,2011,2012\right)$. Moreover, additional estimations were carried out for the period before the crisis (2000-2008) and after the crisis (2009-2012). It allowed for the verification of crisis impacts on the relations between GDP and growth factors covered by the model, including FDI stock.

$\beta$ coefficients illustrate the impact of particular factors (explanatory variables) on the level of economic development. $\varepsilon_{i t}$ error represents unobserved shocks in each time period and country.

Model estimation was performed for data panel with 8 countries from Central and Eastern Europe (The Czech Republic, Estonia, Lithuania, Latvia, Hungary, Poland, Slovenia and Slovakia) in the period of 2000-2012. Statistical data were obtained from two sources: United Nations
Conference on Trade and Development (UNCTAD) (GDP, $G F C F, F D I$, labour force) and Eurostat (HRST).

Estimation techniques typical for panel data (Wooldridge, 2002; Greene, 2003; Maddala, 2006) were applied for the purposes of model structural parameters estimations (Table 1, Figure 4). They allow for the model to cover factors specific for a given object (country) and period (years), which is manifested in the model by the introduction of time series $\left(\alpha_{t} t=1,2, \ldots, T\right)$ and individual effects (cross-section $\alpha_{i} \quad i=1,2, \ldots, N$ ). Therefore it was assumed that the influence of country-specific factors (characteristics) on economic growth level is constant in time, however, spaciously diversified (e.g. geographical location, natural resources as well as other unobservable and omitted aspects in the model), which resulted in individual effects inclusion in the model referring to each $\alpha_{i}$ country. The presence of $\alpha_{t}$ parameters (so called time effect), which represent different intercepts in each year, allows for GDP to change over time (common for all objects (countries)). $\beta$ coefficients on $\mathrm{FDI}_{\mathrm{it}}, \mathrm{GFCF}_{\mathrm{it}},\left(\mathrm{n}_{\mathrm{it}}+\mathrm{g}+\delta\right), \mathrm{HRST}_{\text {it }}$ are assumed constant across years and countries. Such model construction offers extensive opportunities for model application and allows for solving certain econometric problems, e.g. allows to avoid mistakes resulting from omitting an important variable, the application of substitution variables or aggregated data or omitting nonlinear nature of a model (Wooldridge, 2002; Greene, 2003; Dziechciarz, 1993).

Individual effects $\alpha_{\mathrm{i}}$ can be referred to as random or fixed. The choice when individual effects should be regarded as random or fixed is not an easy one. If there are only a few observations available about a given object it becomes extremely important to apply them in a way which allows for capturing differences between the studied objects in the best possible way (Hsiao, 1986). In contemporary econometrics the approach based on random effects is identified with zero correlation between $\alpha_{i}$ omitted individual effect and values of the observed explanatory variables. However, if the term of fixed effects appears in practice it means the possibility of $\alpha_{i}$ and $x_{i t}$ correlation. Literature presents a critical approach to the assumption regarding the absence of correlation between $\alpha_{\mathrm{i}}$ and $\mathrm{x}_{\mathrm{it}}-$ (Mundlak, 1961) effect, since in practice it is difficult to maintain. LSDV model (least squares with dummy variable) (Wooldridge, 2002; Greene, 2003) was used in the procedure of structural parameters estimations.

Whether the introduction of individual effects in a model is founded still has to be verified. In order to assess whether model specification is correct and the introduction of individual effects is founded, The F test (Greene, 2003) was used. The F test allows for checking joint substantiality of artificial variables referring to individual effects for each object (country) of the study. Zero hypothesis referring to constant intercepts (individual effects) can be presented in the following way: $H_{0}: \quad \alpha_{i}=\alpha=$ const, $i=1, \ldots, N$.

Models based on cross-sectional data were estimated using Ordinary Least Square (OLS). Robust HC3 standard errors were applied in determining the significance of structural parameter estimates, which gives an alternative bias correction for the variance calculation as suggested by (Davidson \& MacKinnon, 1993), who reported that this 
method tends to produce better results when the model is really heteroskedastic. $\mathrm{HC} 3$ standard errors produce confidence intervals that tend to be even more conservative.

Autocorrelation or/and hetroskedasticity of unknown origin, present in data structure, pose a frequent burden for models. Heterosckedasticity and autocorrelation consistent estimator HAC (Arellano, 2003) was applied in order to avoid negative consequences of these two phenomena for model assessment.

Akaike information criterion (Akaike, 1974) was used for the purposes of models comparability. It is the measure of relative goodness of the fit of a statistical model. The purpose was to select, from among a few models, the one which minimizes information loss for the "true" model. A model presenting the lowest AIC value is the preferred one. $\mathrm{R}^{2}$ determination coefficient was used as a quality measure of model adjustment to empirical data. It informs about the extent to which the variability of an explained variable is presented by the model which ranges from 0 to 1 . In general, the higher the $\mathrm{R}^{2}$, the better the model fits data. All calculation were made in STATA and GRETL programs.

\section{The Results of Model Estimations}

The results of model estimations, which describe the influence of growth factors regarding economic growth, are presented in Table 1. F statistics values equal 38,6 - 89,9 confirm that including $\alpha_{\mathrm{i}}$ individual effects in the model is fully founded, since as statistically significant they improve estimation results significantly. Test F.results indicate major differences between countries in economic growth processes. Determination coefficient values inform that over $98 \%$ of economic growth variability was explained by models.

The first specification (model with lnHRST variable) covers a full set of variables. After verifying the assessments of structural parameters it turned out that human capital, presented as lnHRST variable, does not have any statistically significant relation with the level of countries, economic growth. However, it has to be emphasized that the exclusion of the variable responsible for human capital from some of the models structure did deteriorate its quality (as compared to model GDP (2000-2012)) - indicated by an increase in Akaike information criterion value. This suggests that it is an important component of economic growth model structure.

The absence of statistical significance between lnGDP and lnHRST could result from the complexity of relations between human capital resources and the size of global production. An important quality of HRST is its relative stability of changes, and in the case of GDP high sensitivity to environmental changes. HRST level was steadily growing (in 2012 this variable value in the majority of countries was higher when comparing to 2000 by about 20 $\%$; the highest increase was recorded in Poland by about 64 $\%$ and Slovenia - by $55 \%$ ), whereas GDP, in the same period of time, doubled or quadrupled respectively. As a result particular economies were gaining various benefits from the available HRST resources. This could be due to specialization and diversification of mid and high-tech sectors' efficiency and thus - their different roles in GDP creation.

Statistically significant relations (at the level of 0,1 or higher) were identified for the remaining economic growth factors: labor force growth, size of invested foreign capital and investment rate.

This indicates the presence of a statistically significant relation between factors illustrated in the right part of the model and economic growth. While comparing to the specification without InHRST variable, no significant differences in the values of structural parameters were observed regarding particular economic growth factors of the GDP (2000-2012) models with lnHRST variable.

A positive sign for the labor force growth rate is striking. In accordance with Solow's model GDP per capita growth rate is reduced by the labor force growth rate due to the diminishing returns to scale. In our example, in the period prior to crisis, the labor force growth rate has increased and the lnGDP per capita has risen almost in the same way. Such anomaly from the assumptions of Solow's neoclassical growth model can indicate certain interference in estimation processes resulting from e.g. external effects of some phenomena, intense changes in the analyzed economies experiencing extensive socio-economic and political transformations as well as growth and thus the absence of statistical dependence between employment rate changes and in GDP per capita. Following the purpose of conducted analyses, i.e. examining relations occurring between InFDI and economic growth, the estimation was reiterated without the employment growth rate variable ( $3^{\text {rd }}$ part table 1.). The estimation values under discussion with $\ln F D I$ and $\ln G D C F$ variables did not change significantly. It confirms the stability of obtained results. Further in the article specification results without $\operatorname{In} H R S T$ variable $\ln \left(n_{i t}+g+\delta\right)$ will be discussed.

The results of economic growth models estimations (with and without $\ln H R S T, \ln \left(n_{i t}+g+\delta\right)$ variables) referring to the Central and Eastern European countries (in the entire period 2000-2012, before 2000-2008 and after 2008 crisis 2009-2012)

\begin{tabular}{|c|c|c|c|}
\hline Specification & Model GDP (2000-2012) & Model GDP (2000-2008) & Model GDP (2009-2012) \\
\hline 1) $\operatorname{lnFDI} I_{i t}$ & $0,436 * * *[0,061]$ & 0,365 *** $[0,051]$ & $0,521 * * *[0,144]$ \\
\hline $\ln G F C F_{i t}$ & $0,171 * * *[0,031]$ & $0,157 * *[0,060]$ & $0,089 * * *[0,011]$ \\
\hline $\ln \left(n_{i t}+g+\delta\right)$ & $0,615^{* *}[0,267]$ & $0,961 * * *[0,350]$ & $0,026 \quad[0,333]$ \\
\hline $\ln H R S T_{i t}$ & $-0,408 * \quad[0,242]$ & $-0,236 \quad[0,207]$ & $0,062 \quad[0,240]$ \\
\hline$C R$ & $0,312 * * *[0,101]$ & - & - \\
\hline Const. & $5,515 * * *[0,856]$ & $5,512 * * *[0,878]$ & $4,001 * * *[0,810]$ \\
\hline $\begin{array}{l}\text { Test } \mathrm{F} \text { (p-value) } \\
\text { Akaike information criterion } \\
\mathrm{R}^{2}\end{array}$ & $\begin{array}{c}47,4(0,000) \\
-243,3 \\
0,98 \\
\end{array}$ & $\begin{array}{c}38,6(0,000) \\
-170,7 \\
0,989 \\
\end{array}$ & $\begin{array}{c}79,7(0,000) \\
-135,6 \\
0,993 \\
\end{array}$ \\
\hline
\end{tabular}




\begin{tabular}{|c|c|c|c|}
\hline Specification & Model GDP (2000-2012) & Model GDP (2000-2008) & Model GDP (2009-2012) \\
\hline 2) $\ln F D I_{i t}$ & $0,392 * * *[0,062]$ & $0,351 * * *[0,049]$ & $0,531 * * *[0,116]$ \\
\hline $\ln G F C F_{i t}$ & $0,182 * * *[0,037]$ & $0,166^{* *}[0,063]$ & $0,089^{* * *}[0,011]$ \\
\hline $\ln \left(n_{i t}+g+\delta\right)$ & $0,525^{*} \quad[0,316]$ & $0,904 * * *[0,314]$ & $0,007 \quad[0,276]$ \\
\hline$C R$ & $0,290 * * *[0,101]$ & - & - \\
\hline Const. & $4,368 * * *[0,401]$ & $4,749 * * *[0,473]$ & $4,139 * * * *[1,106]$ \\
\hline Test $\mathrm{F} \alpha_{i}(p$-value $)$ & $44,0(0,000)$ & $50,5(0,000)$ & $89,9(0,000)$ \\
\hline Akaike information criterion & $-235,6$ & $-170,0$ & $-137,5$ \\
\hline & 0,986 & 0,989 & 0,993 \\
\hline 3) $\ln F D I_{i t}$ & $0,393 * * *[0,063]$ & $0,36 * * *[0,057]$ & $0,531 * * *[0,113]$ \\
\hline $\ln G F C F_{i t}$ & $0,185 * * *[0,039]$ & $0,172 * *[0,065]$ & $0,089 * * *[0,011]$ \\
\hline$C R$ & $0,288 * * *[0,101]$ & - & - \\
\hline Const. & $4,364 * * *[0,415]$ & $4,692 * * *[0,553]$ & 4,138 *** $[1,083]$ \\
\hline Test $\mathrm{F} \alpha_{i}(p$-value $)$ & $44,1(0,000)$ & $40,9(0,000)$ & $95,3(0,000)$ \\
\hline Akaike information criterion & $-236,6$ & $-169,3$ & $-139,5$ \\
\hline & 0,986 & 0,988 & 0,993 \\
\hline
\end{tabular}

In the presentation of results individual $\alpha_{i}$ and time effects $\alpha_{t}$ were omitted.*** significant at the level of 0,001; ** significant at the level of 0,05; * significant at the level of 0,1. Arellano robust standard error HAC is quoted in parentheses []. Source: Author's compilation in GRETL program.

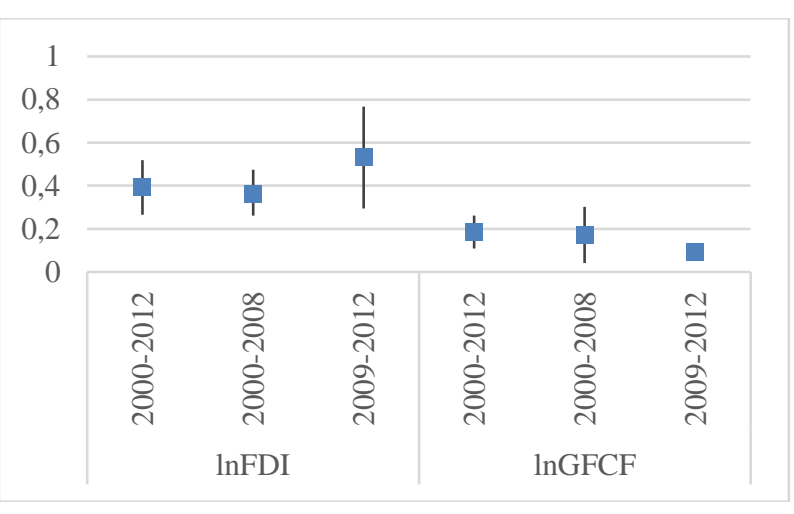

Figure 4. The statistically significant coefficient (at the level 0,05 ) with a $95 \%$ confidential interval of economic growth models estimations (excluding $\ln H R S T, \ln \left(n_{i t}+g+\delta\right)$ variables) referring to Central and Eastern European countries (in the whole period 2000-2012, and before (2000-2008) and after the 2008 crises (2009-2012))

Source: Author's compilation in GRETL programme

The analysis of models' estimations for the period before and after crisis indicated certain differences in the level of estimated parameters. For the purposes of better presentation parameter estimations including a $95 \%$ confidence interval are shown in Figure 4. Basic differences in the level of coefficients in the period before and after the crisis refer to:

- $\ln F D I$ impact on $\ln G D P$ - this relation was characterized by higher elasticity in the second period after the crisis: before the crisis an increase of foreign direct investment stock by $1 \%$ was translated into $0,36 \%$ rise of economic growth level (ceteris paribus); while after the crisis the respective relation was $0,531 \%$;

- $\ln G F C F$ impact on $\ln G D P$ - after the crisis the impact of domestic investment rate on $\ln G D P$ level was inconsiderable: before the crisis an increase of $\ln G F C F$ by $1 \%$ was translated into $0,172 \%$ increase of economic growth level (ceteris paribus); while after the crisis the respective relation was only $0,089 \%$; it was due to a much stronger $\ln G F C F$ reaction to the crisis and a strong decline in their value comparing to $\ln G D P$ level changes.
Panel models offer a general outlook on the relations combining the analysed phenomena jointly for all countries (considering their specificity by introducing individual effects). For better understanding of FDI importance in terms of particular economies, estimations were reiterated based on specification 3 (only $\ln F D I$ and $\ln G D C F$ variables) for each country separately (Figure 5). It was based on cross-sectional data. Due to a limited number of observations (especially for the post crisis period) the analysis was limited to a model covering the entire period (2000-2012). The obtained models were characterized by a high adjustment level to empirical data $\left(\mathrm{R}^{2}\right.$ values ranged from 0,962 to 0,994 ).

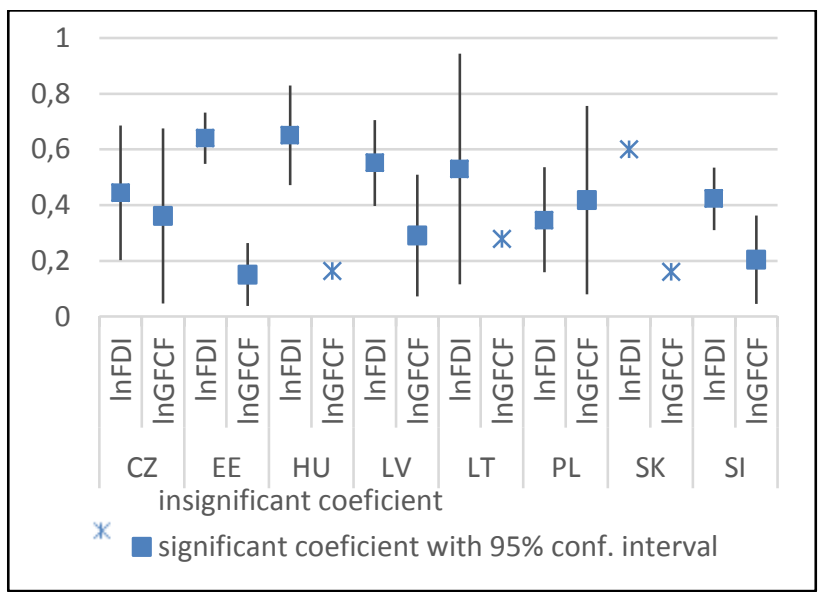

Figure 5. The coefficients (at the level of 0,05 ) with a $95 \%$ confidential interval of economic growth models estimations referring to particular Central and Eastern European countries in the period 2000-2012

Source: Author's compilation in STATA programme

Slovakia was the only country in the case in which both explanatory variables did not present any statistically significant relation with $\ln G D P$ changes. It means that changes in $\ln G D P$ did not correlate with the strength and direction of changes in $\ln F D I$. Parameter estimations, with $\ln F D I$ variable were statistically significant for the other countries. $\ln F D I$ elasticity presented a higher level than $\ln G F C F$ (excluding Poland) and ranged (ceteris paribus) 
from $0,423 \%$ in Slovenia up to $0,65 \%$ in Hungary. In Poland, foreign capital elasticity against $\ln G D P$ changes was lower and amounted to $0,344 \%$, whereas the elasticity of $\ln G F C F$ variable $-0,418 \%$. As mentioned above, Poland was the only country in which elasticity against investments exceeded the elasticity level against foreign capital. In the other countries (for which statistically significant estimations were obtained), i.e. the Czech Republic, Estonia, Latvia, Slovenia - elasticity against investments ranged from $0,151 \%$ (Estonia) up to $0,361 \%$ (The Czech Republic) ceteris paribus. In Hungary and Lithuania elasticity against $\ln G F C F$ did not present any statistically significant relation with $\ln G D P$ changes.

In general, economic growth shows significant relations with the invested foreign capital in particular countries, FDI stock increase has impact on economic growth, however, economic growth is slower than foreign capital increase in a particular country. This dependence was visible in the entire period covered by the study and the dependence between FDI stock and GDP remained more pronounced after the crisis.

\section{Conclusion}

Foreign direct investment in Central and Eastern European countries has been a major indicator of economic development and external economic trust in the stability and development of their economies. During the economic transformation, the foreign direct investments in the countries of Central and Eastern Europe have become an important indicator of the economic development and an indicator of external economic confidence in stability and development of their economy. National governments expected from the foreign direct investments inflow that the foreign investors will restrict economic and social impacts of transformation and contribute to growth of competitiveness of the economies, which is confirmed by positive impact of the foreign investments on export and growth of gross added value in companies under foreign control.

The aim of the article was analysis of the differences in the foreign direct investments inflow among the selected Central and Eastern European countries with special focus on analysis of the influence of the foreign direct investments on the economic growth. The development of the spatial placement of the foreign direct investments per labour force before 2012 is highly imbalanced between the countries. First, the inflow of the foreign direct investments has been characterized since 2000 by dynamic growth, later attenuated at the end of the monitored period by the world economic crisis.

The highest volume of the foreign direct investments per labour force was achieved in Estonia and in the Czech Republic, which is influenced in the Baltic countries by building of the open and export economy with the use of the geographical position of the countries. In the case of the Czech Republic and Slovakia, the investments from Germany have been reflected in the inflow of the foreign direct investments, where the highest volume of the export is directed, which influences the growth of the gross domestic product. Lower growth of the foreign direct investments inflow is, on the other hand, reflected in
Slovenia and Hungary. Slovenia employed a rather passive policy with respect to the foreign investments; Hungary is much more active in the long-term run and therefore, it achieved a higher volume of the implemented foreign investments per capita earlier and the inflow stagnates now. Deteriorated macro-economic situation of the countries influenced negatively the current slowdown of the foreign direct investments inflow to both countries.

The other result of the analysis was estimates of models based on the Endogenous Growth Model. The evaluation of structural parameters (panel models) showed that statistically significant relations exist between economic and FDI, investment growths. The growth of foreign direct investment positively demonstrates itself in increasing the rate of growth of the gross domestic product in all analysed periods 2000-2008; 2009-2012 and all 2000-2012. The growth model also points to the fact that with regards to foreign direct investment, its growth will have an even more marked impact on the gross domestic product developments than was the case for gross fixed capital formation. The elasticity of $\ln F D I$ is under 1 , what means that $\ln G D P$ rise is slower than foreign direct investments. In the period 2009-2012 the elasticity was higher than in the previous period 2000-2008 (but still under 1), It indicates that after the 2008 crises the changes in $\ln F D I$ values would yield to faster economic growth according the changes before time of the crises.

Taking into account results of the econometric analyses for the whole period for particular countries in most of them (excluding Poland and Slovakia) changes in FDI stock have an even greater impact on economic growth that the values of GFCF.

Integration of the countries of Central and Eastern Europe to the European Union increased inflow of the foreign direct investments and accelerated the process of integration of economies into the European and global production chains. The ongoing internationalisation of the economic relationships will reflect in the future in expansion of the production capacities worldwide and the structure of company networks will lose its strong link to its country of origin over time.

During the era of the economic crisis, certain instability in the development processes appears, as well as in mutual dependency between the growth factors, and the development trajectories of the CEEC countries became more differentiated.

Finally, it could be said that both domestic as well as foreign direct investments contribute to the economic growth of the countries of Central and Eastern Europe and growing competitiveness of Central Europe in the global economy. The future risk, which starts to appear, is successive reduction in the inflow of the foreign direct investments of the investors who start to place their investments in more cost-effective countries in Europe and in the world. The reason is the growth of production costs in the CEEC countries that should create the environment attractive for the investments of higher added value. In terms of future development, according to Tun, AzmanSaini \& Law (2012), institutional quality will have a bigger role to play than market size and quality of infrastructure. 


\section{Acknowledgement}

This paper is supported by Internal Grant Agency of Jan Evangelista Purkyne University in Ústi nad Labem in the Czech Republic.

\section{References}

Akaike, H. (1974). A new look at the statistical model identification. IEEE Transactions on Automatic Control, 19(6), 716723. http://dx.doi.org/10.1109/TAC.1974.1100705

Arellano, M. (2003). Panel Data Econometrics. Oxford, England: Oxford University Press. http://doi:10.1093/ 0199245282.001 .0001

Bandelj, N. (2010). How EU Integration and Legacies Mattered for Foreign Direct Investment into Central and Eastern Europe. Europe-Asia Studies, 62(3), 481-501. http://doi:10.1080/09668131003647846

Blažek, J. (2012). Regionalni inovacni systemy a globalni produkcni site: dvoji optika na zdroje konkurenceschopnosti v soucasnem svete? Geografie, 117(2), 209-233. Retrieved from http://geography.cz/sbornik/clanky-z-geografie-20122ke-stazeni-249/

Boudier-Bensebaa, F. (2005). Agglomeration economies and location choice: Foreign direct investment in Hungary. Economics of Transition, 13(4), 605-628. doi: 10.1111/j.0967-0750.2005.00234.x

Bucar, M., Rojec, M., \& Stare, M. (2009). Backward FDI linkages as a channel for transferring technology and building innovation capability: The case of Slovenia. European Journal of Development Research, 21(1), 137-153. http://doi:10.1057/ejdr.2008.11

Carstensen, K., \& Troubal, F. (2004). Foreign direct investment in Central and Eastern European countries: a dynamic panel analysis. Journal of Comparative Economics, 32, 3-22. http://doi:10.1016/j.jce.2003.11.001

Curwin, K., \& Mahutga, M. (2014). Foreign Direct Investment and Economic Growth: New Evidence from Post-Socialist Transition Countries. Social Forces, 92(3), 1159-1187. http:// doi:10.1093/sf/sot128

Davidson, R., \& MacKinnon, J. (1993). Estimation and Inference in Econometrics. London, England: Oxford University Press.

Dziechciarz, J. (1993). Ekonometryczne modelowanie procesow gospodarczych: Modele ze zmiennymi $i$ losowymi parametrii. Wrocław, Poland: Akademia Ekonomiczna.

Estrin, S., Hanousek, J., Kocenda, E., \& Svejnar, J. (2009). The Effects of Privatization and Ownership in Transition Economies. Journal of Economic Literature, 47(3), 699-728. http://doi: 10.1257/jel.47.3.699

Gauselmann, A., Knell, M., \& Stephan, J. (2011). What drives FDI in Central-Eastern Europe? Evidence from the IWHFDI-Micro database. Post-Communist Economies, 23(3), 343-357. http://doi:10.1080/14631377.2011.595148

Ginevicius, R., \& Tvaronaviciene, M. (2003). Globalization processes in Baltic countries: Analysis of trends in Lithuania, Latvia and Estonia. Journal of Business Economics and Management, 4(1), 62-71. http://doi:10.1080/16111699. 2003.9636039

Ginevicius, R., \& Tvaronaviciene, M. (2005). Inward and outward FDI in Lithuania and Estonia: Review of patterns in neighboring countries. Journal of Business Economics and Management, 6(3), 179-188. http://doi:10.1080/16111699. 2005.9636106

Ginevicius, R., \& Simelyte, A. (2011). Government incentives directed towards foreign direct investment: a case of Central and Eastern Europe. Journal of Business Economics, 12(3), 435-450. http://doi:10.3846/16111699.2011.599415

Gomułka, S. (2006). Mechanism and sources of world economic growth. 1-26. Retrieved from http://www.pte.pl/pliki/1/ 210/ SG-econ-growth.pdf.

Gorynia, M., Nowak, J., \& Wolniak, R. (2007). Motives and modes of FDI in Poland: An exploratory qualitative study. Journal for East European Management Studies, 12(2), 132-151. Retrieved from http://hdl.handle.net/10419/83994

Greene, W. H. (2003). Econometric analysis. New Jersey, USA: Pearson Education International.

Hardy, J., Micek, G., \& Capik, P. (2012). Upgrading Local Economies in Central and Eastern Europe? The Role of Business Service Foreign Direct Investment in the Knowledge Economy. European Planning Studies, 19(9), $1581-1591$. http://doi:10.1080/09654313.2011.586180

Hlavacek, P. (2009). The Foreign Direct Investments In The Usti Region: Theory, Actors And Space Differentiation. E \& M Ekonomie and Management, 12(4), 27-39.

Hlavacek, P., \& Koutsky, J. (2011). The Polarisation Tendencies in Localization of Foreign Direct Investments in the Czech Republic. In A. Kocourek, M. Ortova \& D. Mysakova (Eds.). 10th International Conference of Liberec Economic Forum. Paper presented at the Technical University of Liberec, Liberec, 19-20 September (pp.186-194). Liberec, Czech Republic: Technical University of Liberec.

Hsiao, Ch. (1986). Analysis of panel data. Cambridge, England: Cambridge University Press. 
Petr Hlavacek, Beata Bal-Domanska. Impact of Foreign Direct Investment on Economic Growth in Central and Eastern...

Kornai, J. (2006). The great transformation of Central Eastern EuropeSuccess and disappointment. Economics of Transition, $4(2), 207-244$. Retrieved from http://www.kornai-janos.hu/Kornai2006\%20The\%20great\%20 transformation\% 20\%20EconTrans.pdf http://dx.doi.org/10.1111/j.1468-0351.2006.00252.x

Kornecki, L., \& Raghavan, V. (2011). FDI Stock and Growth in Central and Eastern Europe. The International Trade Journal, 25(5). http://dx.doi:10.1080/08853908.2011.604297

Leibrecht, M., \& Riedl, A. (2014). Modeling FDI based on a spatially augmented gravity model: Evidence for Central and Eastern European Countries. Journal of International Trade, 23(8), 1206-1237. http://doi:10.1080/09638199. 2013.861006

Mundlak, Y. (1961). Empirical Production Functions Free of Management Bias. Journal of Farm Economics, 43(1), 44-56. http://doi:10.2307/1235460

Maddala, G. S. (2006). Ekonometria. Warszawa, Poland: PWN.

Mankiw, N., Romer, D., \& Weil. D. (1992). A Contribution to the Empirics of Economic Growth. The Quarterly Journal of Economics, 107(2), 407-437. http://doi:10.2307/2118477

Pavlinek, P. (2012). The Internationalization of Corporate R\&D and the Automotive Industry R\&D of East-Central Europe. Economic Geography, 88(3), 279-310. http://doi:10.1111/j.1944-8287.2012.01155.x

Popescu, N. (2007). Services trade within Central and Eastern Europe region: determinants, barriers, effects. Amfiteatru Economic, 9 (22), 106-114. Retriewed from http://www.amfiteatrueconomic.ro/RevistaDetalii_EN.aspx? CodArticol=404

Prochniak, M. (2011). Determinants of economic growth in Central and Eastern Europe: the global crisis perspective. PostCommunist Economies, 23(4), 449-468. http://doi:org/10.1080/14631377.2011.622566

Rapacki, R., \& Prochniak, M. (2009). Economic Growth Accounting in Twenty-Seven Transition Countries,1990-2003. Eastern European Economics, 47(2), 69-112. http://doi:10.2753/EEE0012-8775470205

Revina, I., \& Brekis, E. (2009). Foreign Direct Investment and Economic Growth in Latvia. Economic Science for Rural Development Conference Proceedings, 18, 142-149.

Romer, P. (1986). Increasing returns and long-run growth. Journal of Political Economy, 94(5), 1002-1037. Retrieved from http://www.parisschoolofeconomics.eu/docs/darcillon-thibault/paul-romer-increasing-returns-and-long-rungrowth.pdf http://dx.doi.org/10.1086/261420

Romer, P. (1990). Endogenous technological change. Journal of Political Economy, 98(5), 71-102. http://doi:10.3386/ w3210

Tokarski, T. (2005). Statystyczna analiza regionalnego zrożnicowania wydajności pracy, zatrudnienia $i$ bezrobocia $w$ Polsce. Warszawa, Poland: PWE.

Tousek, V., \& Tonev, P. (2003). Foreign Direct Investment in the Czech Republic (with the emphasis on border regions). Acta Universitatis Carolinae-Geographica, 38(1), 445-447.

Turnock, D. (2005). Foreign Direct investment and Regional Development in East Central Europe and the Former Soviet Union. Adlershot, England: Ashgate Publishing Limited.

Tvaronaviciene, M., \& Grybaite,V. (2007). Impact of FDI on Lithuanian economy: Insight into development of main economic activities. Journal of Business Economics and Management, 8(4), 285-290. http://doi:10.1080/16111699. 2007.9636181

Wokoun, R., Tvrdon, J., \& Damborsky, M. (2010). Prime zahranicni investice a regionalni rozvoj. Prague, Czech Rep.: Oeconomica.

Wooldridge, J. M. (2002). Econometric analyses of cross section and panel data. Cambridge, Massachusetts: MIT Press. https://jrvargas.files.wordpress.com/2011/01/wooldridge_j-_2002_econometric_analysis_of_cross_section_ and_panel_data.pdf

Tun,Y., Azman-Saini, W. N. W., \& Law, S. (2012). International Evidence on the link between Foreign Direct Investment and Institutional Quality. Inzinerine Ekonomika-Engineering Economics, 23(4), 379-386. http://dx.doi:10.5755/ j01.ee.23.4.2569

Yucel, G. E. (2014). FDI and Economic Growth: The Case of Baltic Countries. Research in World Economy, 5(2), $115-134$. http://dx.doi:org/10.5430/rwe.v5n2p115

The article has been reviewed.

Received in March, 2013; accepted in June, 2016. 